development.

Kellner, D. \& Share, J. (2005). Toward critical media literacy: Core concepts, debates, organizations and policy. Discourse: Studies in the Cultural Politics of Education, 26(3), 369-386.

Kubey, R. (1998). Obstacles to the Development of Media Education in the United States. Journal of Communication, 48(1), 58-69.

Kupersmidt, J. B., Scull, T. M. \& Austin E. W. (2010). Media literacy education for elementary school substance use prevention: Study of media detective. Pediatrics, 126(3), 525-531.

Piette, J. \& Giroux, L. (1996). The theoretical foundations of media education programs. In R. Kubey (Ed.), Media literacy in the information age (pp. 89-134). New Brunswick, NJ: Transaction.

RobbGrieco, M. \& Hobbs, R. (2013). A Field Guide to Media Literacy Education in the United States. Kingston: Media Education Lab Harrington School of Communication and Media University of Rhode Island.

Walsh, D. (1998). Video and Computer Game Report Card. Minneapolis, MN: National Institute on Media and the Family.

УДК 351.851:374.7 (48)

DOI: https://doi.org/10.35387/od.2(16).2019.155-166

Огієнко Олена Іванівна - доктор педагогічних наук, профресор, професор кафедри педагогіки Сумського державного педагогічного університету імені А.С. Макаренка

ORCID ID: https://orcid.org/0000-0002-3089-6288

E-mail: el.ogienko@gmail.com

\title{
СУСПІЛЬНО-ДЕРЖАВНЕ УПРАВЛІННЯ В СИСТЕМІ ОСВІТИ ДОРОСЛИХ: ДОСВІД ШВЕЦІї, ДАНІї, НОРВЕГІЇ ТА ФІНЛЯНДІЇ
}

\begin{abstract}
Анотація. У cmammi проаналізовано підходи до управління системою освіти дорослих у Швеції, Данії, Норвегії та Фінляндії; обгрунтовано сутність суспільно-державного управління системою освіти дорослих; визначено структуру та провідні принципи. Доведено, що саме суспільно-державний характер управління системою освіти дорослих у Швеції, Данії, Норвегії та Фінляндії забезпечує більш повне задоволення освітніх потреб людини, суспільства та держави, гармонійне поєднання децентралізації та централізації, застосування моделі децентралізованого централізму в управлінні освітою дорослих. Структура управління освітою дорослих складається 3 наднаціонального, національного (державного), регіонального, муніципального рівнів та рівня навчального закладу, що забезпечує перерозподіл функцій між органами управління різних рівнів та активну участь громадян в управлінні, тісний зв'язок освіти дорослих з структурами громадянського суспільства. З'ясовано, що основними
\end{abstract}


принципами управління системою освіти дорослих у Швеції, Данії, Норвегії та Фінляндії є принципи: самоуправління, за яким надається широка автономія навчальним закладам; цілеспрямованості, який орієнтує процес управління системою освіти дорослих на інтереси особистості, суспільства та держави; узгодження державних, регіональних, муніципальних інтересів, без якого неможливо проведення єдиної освітньої політики та забезпечення ефрективного управління освітою дорослих; демократизації, що створює умови для залучення громадян у процес управління системою освіти дорослих; партнерства суб`єктів управління, якими є органи центральної, регіональної та муніципальної влади, суспільні об'єднання, організації освіти дорослих, соціальні партнери. Показано, що досвід Швеції, Данії, Норвегії та Фінляндії стосовно управління системою освіти дорослих може бути використаний у розбудові української системи освіти дорослих, і першим кроком повинна стати розробка законодавчою бази, яка регламентує цілі, завдання та фрункції різних рівнів управління, дає можливість адекватно реагувати на освітні потреби дорослих людей.

Ключові слова: освіта дорослих, управління, управління освітою дорослих, суспільно-державне управління, скандинавські країни (Швеція, Данія, Норвегія), Фінляндія.

Ogienko Olena - Doctor of Pedagogical Science, Professor, Professor of the Department of Pedagogy of the A.S. Makarenko Sumy State Pedagogical University

ORCID ID: $h$ ttps://orcid.org/0000-0002-3089-6288

E-mail: el.ogienko@gmail.com

\title{
PUBLIC-STATE MANAGEMENT IN THE ADULT EDUCATION SYSTEMS: THE EXPERIENCE OF SWEDEN, DENMARK, NORWAY AND FINLAND
}

\begin{abstract}
In the article the approaches to management of the adult education systems in Sweden, Denmark, Norway and Finland are analyzes; the essence of social and state management of the adult education system are substantiate; structure and main principles are defined. Social-state nature of the management of the adult education system in Sweden, Denmark, Norway and Finland provides more complete satisfaction of the educational needs of the individual, society and the state, the harmonious combination of decentralization and centralization, the application of the decentralized centralism model in the management of adult education. The structure of adult education management consists of supranational, national (state), regional, municipal and educational levels, which provides for the redistribution of functions between the various levels of government and the active participation of citizens in management, close communication of adult education with the structures of civil society. It has been established that the basic principles for managing the adult education system in Sweden, Denmark, Norway and Finland are the following: self-
\end{abstract}


government, which gives broad autonomy to schools; commitment, which guides the process of managing the adult education system to the interests of the individual, society and the state; harmonization of state, regional, municipal interests, without which it is impossible to carry out a single educational policy and ensure effective management of adult education; democratization, which creates the conditions for involving citizens in the process of managing the adult education system; partnerships of management entities, which are bodies of central, regional and municipal authorities, public associations, adult education organizations, social partners. It is shown that the experience of Sweden, Denmark, Norway and Finland in the management of the adult education system can be used in the development of the Ukrainian adult education system, and the first step should be the development of a legislative framework that regulates the goals, objectives and functions of the various levels of government, provides an adequate response for the educational needs of adults.

Key words: adult education, management of adult education, publicstate management, Scandinavian countries (Sweden, Denmark, Norway), Finland.

Постановка проблеми, її актуальність. Сучасний етап розвитку суспільства характеризується динамічними змінами в усіх сфера соціально-економічного, науково-технічного та культурного життя. У зв'язку з цим підвищується значущість освіти дорослих, яка здатна забезпечити самореалізацію дорослої людини, задовольнити освітні потреби як конкретної дорослої людини, так і суспільства та держави в цілому. Це актуалізує формування освітньої політики щодо освіти дорослих, зумовлює особливості її функціонування та управління.

До основних факторів, які визначають цілі управління освітою дорослих, відносяться освітні потреби суспільства, держави, виробництва, різних організацій, окремих людей. Тому управління освітою дорослих розглядають як діяльність державних, регіональних і муніципальних (місцевих) органів влади, суспільних організацій та громадян, що спрямована на фрормування та здійснення освітньою політики з метою забезпечення прав громадян на неперервну освіту, більш повне задоволення їх освітніх потреб, розвиток освіти дорослих як соціального інституту (Огієнко, 2019).

Для України створення системи освіти дорослих та організація управління нею $є$ одним з найважливіших завдань, яке потребує негайного вирішення. Вважаємо, що аналіз та узагальнення європейського, зокрема, досвіду Швеції, Данії, Норвегії та Фінляндії, буде цьому сприяти. Зазначимо, що ці країни мають тривалі традиції та певні надбання щодо управління системою освіти дорослих, які базуються на врахуванні особливостей північноєвропейського менталітету та гуманістичних цінностях, що особливо важливо та $\epsilon$ визначальним при розвитку української системи освіти (Огієнко, 2008). 
Аналіз останніх наукових досліджень і публікацій. Аналіз наукової літератури показав, що вчені (І. Іванюк, В. Луговий, В. Кремень, В. Луговий, Н. Ничкало, Н. Протасова, Ф. Ван Вагт, Дж. Вайс, Б. Гінзбург, Дж. Груф, Дж. Івек, П. Маасет, К. Моррісон, Г. Нів та ін.) досліджували різні аспекти управління освітою. У контексті нашого дослідження, актуальними $\epsilon$ праці таких вчених-компаративістів як: Н. Авшенюк, Т. Десятов, М. Лещенко, Л. Пуховська, А. Сбруєва, та ін., які вивчали зарубіжний досвід стосовно управління освітою; В. Горшкова, С. Полутина, В. Подобед та ін., які приділяли увагу проблемі державно-суспільного управління освітою дорослих. Проте, аналізу та узагальненню досвіду Швеції, Данії, Норвегії та Фінляндії щодо фрормування структур управління у галузі освіти дорослих не приділялося достатньо уваги.

Мета статті - визначення та обґрунтування структури, принципів та особливостей суспільно-державного управління системою освіти дорослих у Швеції, Данії, Норвегії та Фінляндії.

Виклад основного матеріалу дослідження. Розглядаючи освіту дорослих як рушійну силу суспільного прогресу та конкурентноздатності, Данія, Швеція, Норвегія та Фінляндія розробляють освітню політку у відповідності 3 соціально-економічними цілями розвитку. Важливим принципом формування освітньої політики у скандинавських країнах стосовно освіти дорослих є залучення людей у формування та здійснення освітньої політики, що розглядається як важлива передумова активної участі громадян у державних справах демократичного суспільства. Це забезпечує тісний зв язок освіти дорослих з структурами громадянського суспільства (Подобед, 2000; Milana, 2012). Крім цього, можна виділити такі принципи освітньої політики скандинавських країн: пріоритет людських цінностей; пріоритет вільного розвитку особистості; формування громадянськості, поваги до прав і свободам громадян, любові до своєї країни, сім'ї, оточуючому середовищу, тощо; рівність у доступу до освіти; адаптованість системи освіти до рівнів та особливостям підготовки тих, хто навчається; свобода та плюралізм; демократичний, суспільно-державний характер управління (Огієнко, 2008). Дотримання цих принципів гарантує встановлення на основі суспільної згоди конкретних цілей та завдань розвитку системи освіти дорослих та втілення їх у життя шляхом узгоджених дій держави та суспільства. Це досягається завдяки ефективному управлінню системою освіти дорослих.

В організації управління освітою дорослих беруть участь не тільки органи державної влади, муніципалітетів, а й місцева спільнота, різні громадські організації, окремі групи населення, професійні групи тощо, які виступають водночас у деяких іпостасях: як законодавці, що встановлюють правові основи функціонування та розвитку освіти дорослих; як фінансисти освіти дорослих; як замовники та споживачі кадрів, що готує система освіти дорослих; як координатори діяльності стосовно функціонуванню системи освіти дорослих; як політична сила, що здатна у значні мірі визначати відношення всього суспільства до проблем розвитку освіти дорослих 
(Ogienko, 2018).

Підкреслимо, що при організації управління системою освіти дорослих акцент робиться на розвитку місцевої ініціативи, тому системи освіти дорослих Швеції, Данії, Норвегії та Фінляндії традиційно характеризувалися як національні системи, що базуються на місцевій ініціативі та регулюються на муніципальному рівні.

Державні органи не володіють виконавчої владою. У цьому питанні пріоритет мають муніципальні органи, які наділені широкою автономією щодо розвитку освіти дорослих та розподілу фінансування. На державні органи покладена відповідальність за розробку загальної стратегії розвитку системи освіти дорослих, визначення національних цілей, надання фінансової підтримки та контроль. У Данії, наприклад, реформа 2001 р. встановила розподілену відповідальність стосовно освіти дорослих між державними, регіональними та місцевими органами влади (Jakobsen, 2008), а у Фінляндії, Швеції та Норвегії домінуючими є муніципалітети (Огієнко, 2006; Rubenson, 1994; Rinne, 2000).

Наголосимо, що у 1976 р. у Норвегії був прийнятий перший в Європі Закон про освіту дорослих. Прийняття Закону про освіту дорослих мало суттєвий вплив на подальшій розвиток освіти дорослих у цій країні, оскільки затверджувало відхід від державного управління системою освіти дорослих та перехід до децентралізації в управління цією галуззю освіти (Bjerkaker, 2016).

На думку М. Брау (М. Bray), існує два основних виміри децентралізації: функціональна та територіальна децентралізація. Перша передбачає зміни у розподілі повноважень між паралельними владами, а друга -перерозподіл контролю між органами управління в залежності від їх географрічного розташування: від уряду до муніципалітетів. На його думку, можна виділяти декілька підкатегорій і варіантів децентралізації. Наприклад, перерозподіл повноважень між міністерствами, між місцевими органами влади тощо. Фактична повна децентралізація відбувається при передачі повноважень між рівнями, наприклад, від центрального до регіонального, від регіонального до окружного, від окружного до місцевого, від місцевого до рівня навчальних закладів (Bray, 1999, с. 208-210).

Управління освітою дорослих у Швеції, Данії, Норвегії та Фінляндії відрізняється досить високим рівнем децентралізації, яка означає такий перерозподіл функцій і повноважень між центральними, регіональними та муніципальними органами управління, який забезпечує високу ініціативу та самостійність на місцях, узгодження державних, регіональних та муніципальних інтересів (Lundahl, 2002).

Водночас, децентралізація управління системою освіти дорослих у розвинених північноєвропейських країнах спрощує структуру, скорочує чисельність апарату управління, забезпечує та активізує самоуправлінність освітніх структур у системі освіти дорослих. Тому ми вважаємо, що одним із основних принципів управління системою освіти дорослих у визначених країнах $€$ принцип самоуправління. За цим принципом, наприклад, 
надається широка автономія закладам освіти, що передбачає їх повну фінансову, господарську та професійну самостійність.

Поряд із принципом самоуправління важливого значення набув і принцип цілеспрямованості, який орієнтує процес управління системою освіти дорослих на інтереси особистості, суспільства та держави. 3 ним тісно пов язаний принцип узгодження державних, регіональних, муніципальних інтересів, без якого неможливо проведення єдиної освітньої політики та забезпечення ефективного управління освітою дорослих.

Принцип демократизації проходить червоною стрічкою через діяльність різних управлінських структур у країнах і в управлінні системою освіти дорослих відіграє головну роль, забезпечуючи вплив громадськість на процес управління та прийняття рішень.

Принцип демократизації узгоджується з принципом партнерства суб єктів управління, якими є органи центральної, регіональної та муніципальної влади, суспільні об`єднання, організації освіти дорослих, соціальні партнери (Boström, 2017). Це дає можливість гнучко та оперативно реагувати на всі зміни, які відбуваються у суспільстві та керуватися формулою «економіка - соціальні відношення - освіта», що, у свою чергу, дає можливість орієнтуватися не тільки на потреби економіки, а й враховувати соціальне замовлення суспільства, надавати рівні можливості для одержання освіти дорослому населення у Швеції, Данії, Норвегії та Фінляндії.

Вважаємо, що для систем освіти дорослих означених країн базовим $€$ принцип суспільно-державного характеру управління, який означає, що управлінська діяльність здійснюється усіма структурами громадянського суспільства в Швеції, Данії, Норвегії та Фінляндії як державними, так і громадськими, до останніх відносяться добровільно сформовані асоціації освіти дорослих, об єднання громадян різного спрямування, організації, рухи, які вільні від урядового контролю та можуть впливати на освітню політику в освіті дорослих.

Наші розвідки засвідчують, що принцип суспільно-державного характеру управління забезпечує: відкритість освіти дорослих для громадськості; врахування інтересів та освітніх потреб широкого кола населення; залучення дорослих людей до обговорення, ініціювання пропозицій та прийняття рішень у сфері освіти дорослих; дієву, активну участь громадськості в співуправлінні закладами освіти та місцевому самоуправлінні; вплив суспільства на якість освіти дорослих та її доступність; підвищення ефективності діяльності закладів освіти дорослих і всієї системи загалом; динамічність та адаптованість до вимог сьогодення; розвиток соціального партнерства.

Отже, централізація управління освітою дорослих у Швеції, Данії, Норвегії та Фінляндії дивним чином сполучається 3 максимальною децентралізацією та самостійністю місцевих органів при формуванні структури освіти дорослих. Держава фактично позбавлена виконавчих повноважень і повноважень оперативного управління, воно здійснює лише 
загальне законодавче регулювання та значну частину фінансування. Водночас, Міністерства освіти та відомства здійснюють контроль за діяльністю муніципалітетів щодо освіти дорослих, а на регіональному рівні (рівні округів) існує спеціальний колегіальний орган - контрольний комітет.

Отже, вивчаючи організацію управління системами освіти дорослих у Швеції, Данії, Норвегії та Фінляндії, ми прийшли до висновку, що для цих країн характерно гармонійне поєднання децентралізації та централізації в управлінні освітою дорослих. Йдеться про модель децентралізованого централізму в управлінні освітою дорослих. Проте, перехід до неї здійснюється досить повільними темпами та, на відміну, наприклад, від англійської системи управління освітою дорослих, коло функцій місцевої влади стосовно розвитку освіти дорослих не зменшується, а, навпаки, з одного боку, посилюється її відповідальність перед державними органами, а з іншого - посилюється контроль за розподілом фінансів та якістю освіти з боку державних органів. Тому, на сьогоднішній день, побоювання Пітера Джарвіса, що втручання центрального уряду у сектор освіти дорослих перетворить ії у суто професійний, ринково-орієнтований сектор, який дбає тільки про інтереси економіки та нехтує духовними і культурними потребами громадян (Jarvis, 1993) не мають підстав у контексті розвитку системи освіти дорослих у Швеції, Данії, Норвегії та Фінляндії.

Аналіз законодавчої бази освіти дорослих свідчить про те, що управління освітою дорослих у Швеції, Данії, Норвегії та Фінляндії здійснюється на декількох рівнях: національному, регіональному, муніципальному (локальному) та рівні навчального закладу. Зазначимо, що кожен з цих рівнів являє собою мережу як з державних, так і недержавних інституцій, які виконують різноманітні функції та завдання ((Jakobsen, 2008; Bjerkaker, 2016; Rinne, 2000; Rubenson, 1994).

Структуру управління системою освіти дорослих доцільно розглядати як сукупність органів державної влади, недержавних організацій та суспільних об`єднань, які пов`язані між собою та взаємодіють на основі демократичних принципів та скоординованої участі у розробці та прийнятті рішень 3 метою досягнення оптимальних результатів, які передбачені змістом освітньої політики (Подобед, 2000). Зауважимо, що провідними функціями органів управління освітою дорослих у Швеції, Данії, Норвегії та Фінляндії на національному рівні $є$ : розробка стратегії функціонування та розвитку освіти дорослих у сучасних умовах; визначення джерел фінансування та самофінансування державних, регіональних, муніципальних та приватних закладів освіти дорослих; координація діяльності регіональних та муніципальних органів управління освітою дорослих; моніторинг системи освіти дорослих.

Основним державним органом управління на національному рівні $€$ Міністерство освіти, яке переважно відповідає за прийняття законів, тоді як організація та безпосередній контакт 3 регіональними та муніципальними структурами здійснюють спеціально створені 
Департаменти (Фінляндія), Комісії (Норвегія, Ісландія) (Bjerkaker, 2016) чи Національні Правління Освітою (Швеція, Данія) (Boström, 2017). Ці структури зазвичай мають незалежний статус. Вони мають повноваження ухвалювати рішення стосовно поточного управлінням в освітньому секторі. В їх обов'язки входить представлення Уряду пропозицій освітніх реформ. Вони відповідають за значну частину планування, моніторингу та реалізації урядової політики у галузі освіти взагалі, та освіти дорослих, зокрема. Так, наприклад, фрормування щорічного бюджету залежить від висновків та розробок правління.

Однією з важливих задач Національного Правління Освіти є гарантування того, що діяльність у сфері освіти фрактично відповідає директивам, прийнятим Урядом. Так, Національне Правління Освіти Швеції охоплює п'ять секцій, серед яких є сектор освіти дорослих, організований 1 липня 1972 р. Ця секція складається з Бюро муніципальної освіти дорослих, Бюро ліберальної освіти дорослих (їй підпорядковуються вищі народні школи та навчальні гуртки, які організовуються асоціаціями освіти дорослих та спонсоруються професійними союзами), а також Спеціальне бюро, яке відповідальне за курси навчання для ринку праці (Boström, 2017).

Як і в інших скандинавських країнах, у Данії відповідальність за функціонування системи освіти дорослих розподілена між трьома рівнями управління: держава, регіони, муніципалітети. Держава здійснює стратегічне управління освітою дорослих, залучаючи Міністерство освіти, яке складається 3 трьох управлінь: Національного управління освітою (Uddannelsesstyrelsen), що займається правовими питаннями на всіх рівнях системи освіти; Національного управління по справам навчальних закладів (Institutionsstyrelsen), яке контролює стан фрінансів, субсидій та загальних питань навчальних закладів та Національного агентства з освітніх кредитів та субсидій (SU-styrelsen), що займається розподілом субсидій, які виділяються державою (у межах Statens Uddannelsesstøtte, SU - державної програми стипендій та освітніх кредитів, а також Statens Voksenuddannelsesstøtte, SVU - державної програми надання стипендій для дорослих). Регулюванням професійної освіти дорослих та навчанням для ринку праці, виробничих шкіл для молоді та резидентними народними вищими школами (домашнього типу) опікується держава

Регіональні (графьські) інституції беруть на себе відповідальність за базову освіту дорослих та освіту для людей з обмеженнями. Для цього створюються Комітети з освіти та культури, які $\epsilon$ розподільчими та контролюючими органами водночас. Муніципалітети контролюють роботу закладів неформальної освіти та надання освіти іммігрантам (Milana, 2012; Jacobsen, 1994). Проте, зазначимо, що управлінські структури регіонального та муніципального рівня виконують тільки контролюючу функцією щодо розподілу бюджету та якості результатів навчання. Рішення про фрінансування різних видів освіти дорослих та надання субсидій входить до фрункцій Національного правління освітою (сектора освіти дорослих). Воно контролює та оцінює дії муніципалітетів, навчальних 
закладів щодо досягнення поставлених цілей та на основі цього приймає своє обґрунтоване рішення.

Характерною ознакою управління системою освіти дорослих у Швеції, Данії, Норвегії та Фінляндії $€$ автономія закладів освіти дорослих, що зумовлює існування провайдерського рівня управління. До їх компетенції відноситься розробка та реалізація освітніх програм та їх корегування з врахуванням освітніх потреб дорослої людини, суспільства та держави, які швидко змінюються.

Дослідження доводить існування ще одного впливового та інтегруючого рівня управління систем освіти дорослих у Швеції, Данії, Норвегії та Фінляндії - наднаціонального рівня. Його представляє Північна Рада, яка була створена у 1952 р. і Рада Міністрів Північних Країн (РМПК), що працює з 1971 р. Північна Рада - це парламентська асамблея Північних країн. Вона представлена п'ятьома галузевими комітетами, серед яких Комітет по культурі та освіті. Співпраця у межах Ради Міністрів Північних країн (РМПК) здійснюється між урядами Данії, Норвегії, Швеції, Ісландії та Фінляндії, а також адміністраціями трьох самокерованих регіонів Аландських островів, Гренландії та Фарерських островів (Jõgi, 2018).

Проблемами освіти дорослих у РМПК опікується Виконавчий комітет з освіти дорослих. Одним з головних завдань останніх років, на виконання якого спрямована діяльність комітету $\epsilon$ ратифікація освітніх досягнень дорослої людини, яка розглядаються як одна з умов особистого розвитку та просування по кар`єрі. РМПК здійснює свою роботу виходячи 3 загальних цінностей Північних країн: забезпечення прав людини, участь громадян у житті суспільства, загальна соціальна відповідальність, гендерна рівність, повага до національних меншин та різних культур. 3 бюджету РМПК здійснюється повне чи часткове фрінансування загальних інститутів та структур північних країн. Серед них «Центри Північних країн» (Nordens Hus) в Рейк`явіку та Торсхавну, Інформаційно-культурні центри (Norden i Fokus) в Осло, Стокгольмі та Копенгагені, Північний фонд освіти (Nordplus), Північна народна академія (Nordic Folk Academy - NFA). Остання опікувалася безпосередньо проблемами освіти дорослих північних країн. Діяльність академії була спрямована на підтримку, координацію освіти дорослих у скандинавських країнах та інтеграцію та співпрацю з іншими європейськими країнами. Базуючись на загальній для скандинавських країн історії, культурі, однаковим розумінні демократичних цінностей, основними напрямками її роботи були: взаємозв язок між формальною та неформальної освітою, між освітою та ринком праці; компетентнісний підхід, застосування інформаційних технологій, активна громадянська участь у контексті неперервної освіти; міжнародний обмін передовим досвідом (Jõgi, 2018; Milana, 2012).

Важливе значення у структурі наднаціонального рівня має Північна мережа навчання дорослих (Nordiskt Nätverk för Vuxnas Lärande (NVL) (Nordic Network for Adult Learning), якої теж опікується Рада Міністрів Північних країн. Ії̈ стратегічними завданнями є: освіта впродовж життя та 
компетентність, ратифікація особистісної та профресійної компетентності (розвиток методології ратифікації неформальної освіти тощо); якість, індикатори, ефеекивність інвестицій в освіту дорослих; співпраця, що спрямована на конкурентноздатність на ринку праці та у громадянському суспільстві (навчання на робочому місці, навчання у громадянському суспільстві, навчання незаможніх верст населення, тощо); співпраця задля особистісного розвитку громадян та демократичного суспільства, розвиток через підготовку вчителів для дорослих та розвиток методології освіти (групове навчання, гнучке навчання та IT, громадянська освіта, навчання для стійкого розвитку тощо) (Огієнко, 2008).

Таким чином, основними завданнями органів управління освітою дорослих на наднаціональному рівні є: розробка стратегії функціонування та розвитку скандинавської системи освіти дорослих у сучасних умовах; консультування та координація діяльності державних органів управління; розвиток міжкультурного діалогу; підвищення якості освіти дорослих; досягнення еквівалентності систем освіти дорослих скандинавських країн; валідація неформальної освіти; розробка та реалізація освітніх програм та проектів; інтеграція скандинавської системи освіти дорослих до європейського освітнього простору.

Висновки та перспективи подальших досліджень. Узагальнення результатів дослідження дало змогу сформулювати низку висновків щодо управління системою освіти дорослих у Швеції, Данії, Норвегії та Фінляндії: суспільно-державний характер управління забезпечує більш повне задоволення освітніх потреб людини, суспільства та держави; гармонійне поєднання децентралізації та централізації в управлінні освітою дорослих зумовлює застосування моделі децентралізованого централізму в управлінні освітою дорослих; структура управління освітою дорослих складається з п'яти рівнів: наднаціонального, національного (державного), регіонального, муніципального (локального) та рівня навчального закладу, що забезпечує перерозподіл функцій між органами управління різних рівнів та активну участь громадян в управлінні, тісний зв язок освіти дорослих 3 структурами громадянського суспільства; досвід Швеції, Данії, Норвегії та Фінляндії стосовно управління системою освіти дорослих може бути використаний у розбудові української системи освіти дорослих, і першим кроком повинна стати розробка законодавчою бази, яка регламентує цілі, завдання та фрункції різних рівнів управління, дає можливість адекватно реагувати на освітні потреби дорослих людей.

Перспективним і доцільним для подальшого дослідження є вивчення та узагальнення законодавчих $\mathrm{i}$ концептуальних засад формування механізмів реалізації освітньої політики у галузі освіти дорослих у розвинених європейських країнах.

\section{Список використаних джерел}

Подобед, В. И. (2000). Управление образованием взрослых. СПб.: ИОВ PAO. 
Огієнко, О.І. (2006). Розвиток освіти дорослих у Данії: організаційнопедагогічний аспект. Педагогічний процес: теорія і практика, 4, $180-190$.

Огієнко, О. І. (2008). Тенденції розвитку освіти дорослих у скандинавських країнах. Суми: Еллада-S.

Огієнко, О. І., Терьохіна, Н. О. (2019). Неформальна освіта у Сполучених Штатах Америки: історія і сучасність. Суми: СНАУ.

Bray, M. (1999). Control of Education: Issues and Tensions in Centralization and Decentralization. In Arnove R. F., Torres C. A. (Eds.). Comparative Education. The Dialectic of the Global and the Local, pp. 207-232. Boulder: Rowman \& Littlefield Publishers Inc.

Bjerkaker, S. (2016). Adult and Continuing Education in Norway. Potsdam; Susanne Kemmner, DIE.

Boström, A.K. (2017). Lifelong learning in policy and practice: The case of Sweden. Australian Journal of Adult Learning, 57 (3), 334-350.

Jakobsen T. (2008). National developments in education law and policy Denmark. European Journal for Education Law and Policy, 2(1), 71-75.

Jarvis, P. (1993). Adult Education and the State. Towards a policy of Adult Education. London: Routledge.

Jõgi, L., Teresevičienè, M., Kokge, T. \& Carlsen, A. (2018). Nordic-Baltic cooperation in the field of adult education 1991-2004. International Review of Education, 64 (4), 415-419.

Lundahl, L. (2002). From Centralisation to Decentralisation: Governance of Education in Sweden. European Educational Research Journal. 1(4), 625-636

Milana, M. (2012). Political globalization and the shift from adult education to lifelong learning. European Journal for Research on the Education and Learning of Adults, 3 (2), 103-117.

Ogienko, O., Terenko, O. (2018). Non-Formal Adult Education: Challenges and Prospects of 21st Century. Edukacja - Technika - Informatyka, 2(24), 169-174.

Rinne, R. \& Vanttaja, M. (2000). New Directions of Adult Education Policy in Finland. In: Reform and Policy. Adult Education Research in Nordic Countries. Trondheim: Tapir Academic Press.

Rubenson, K. (1994), Adult Education Policy in Sweden 1967-1991. Review of Policy Research. 13 (3-4).

\section{References (translated and transliterated)}

Podobed, V. I. (2000). Adult Education Management. SPb.: IOV RAO (in Russian).

Ohiienko, O .l. (2006). Adult education development in Denmark: organizational and pedagogical aspect. Pedahohichnyi protses: teoriia i praktyka, 4, 180-190 (in Ukrainian).

Ohiienko, O. I. (2008). Trends in Adult Education in Scandinavian Countries. Sumy: Ellada-S (in Ukrainian).

Ohiienko, O. I, Terokhina, N. O. (2019). Non-formal education in the United States of America: history and modernity. Sumy: SNAU (in Ukrainian). 
Bray, M. (1999). Control of Education: Issues and Tensions in Centralization and Decentralization. In Arnove R. F., Torres C. A. (Eds.). Comparative Education. The Dialectic of the Global and the Local, pp. 207-232. Boulder: Rowman \& Littlefield Publishers Inc.

Bjerkaker, S. (2016). Adult and Continuing Education in Norway. Potsdam; Susanne Kemmner, DIE

Boström, A.K. (2017). Lifelong learning in policy and practice: The case of Sweden. Australian Journal of Adult Learning, 57 (3), 334-350

Jakobsen T. (2008). National developments in education law and policy - Denmark. European Journal for Education Law and Policy, 2(1), 71-75.

Jarvis, P. (1993). Adult Education and the State. Towards a policy of Adult Education. London: Routledge.

Jõgi, L., Teresevičienè, M., Kok̦e, T. \& Carlsen, A. (2018). Nordic-Baltic cooperation in the field of adult education 1991-2004. International Review of Education, 64 (4), 415-419.

Lundahl, L. (2002). From Centralisation to Decentralisation: Governance of Education in Sweden. European Educational Research Journal. 1(4)/ 625636

Milana, M. (2012). Political globalization and the shift from adult education to lifelong learning. European Journal for Research on the Education and Learning of Adults, 3 (2), 103-117.

Ogienko, O., Terenko, O. (2018). Non-Formal Adult Education: Challenges and Prospects of 21st Century. Edukacja - Technika - Informatyka, 2(24), 169-174.

Rinne, R. \& Vanttaja, M. (2000). New Directions of Adult Education Policy in Finland. In: Reform and Policy. Adult Education Research in Nordic Countries. Trondheim: Tapir Academic Press.

Rubenson, K. (1994), Adult Education Policy in Sweden 1967-1991. Review of Policy Research. 13 (3-4).

\section{Удк 374.7 (495)}

DOI: https://doi.org/10.35387/od.2(16).2019.166-176

Постригач Надія Олегівна - кандидат біологічних наук, старший науковий співробітник, старший науковий співробітник відділу зарубіжних систем педагогічної освіти і освіти дорослих Інституту педагогічної освіти і освіти дорослих імені Івана Зязюна НАПН України

ORCID ID: https://orcid.org/0000-0002-5433-2938

E-mail: unadya1@gmail.com

\section{ОСОБЛИВОСТІ ЗАСТОСУВАННЯ КАСКАДНОГО ПІДХОДУ В ОСВІТІ ДОРОСЛИХ ГРЕЦЬКОЇ РЕСПУБЛІКИ}

Анотація. У публікації автор аналізує основні характеристики, переваги та вимоги до каскадної моделі навчання та освіти дорослих Грецької Республіки. На основі контент-аналізу літературних джерел проаналізовано зарубіжний досвід, зроблено висновок про те, що Греція - 